\title{
ADYGHEYA: PROCESSES OF RE-ISLAMISATION AND CHALLENGES OF ISLAMIC RADICALISM (1990-2015) ${ }^{1}$
}

\author{
Naima A. Neflyasheva \\ Candidate of Sciences (History), Associate Professor, Senior Researcher, \\ Center for Civilizational and Regional Studies, \\ Institute for African Studies, Russian Academy of Sciences \\ innef@mail.ru \\ Spiridonovka St., 30/1, 123001 Moscow, Russian Federation
}

\begin{abstract}
The article analyzes the transformation of Islamic community of the Adygheya Republic during 1990-2015, new tendencies and actors. The author reveals new trends in the 2010s updated by the dynamics of the political background of Adygheya. The main focus is the factors constraining Muslims from radicalism in the $1990 \mathrm{~s}-2010 \mathrm{~s}$, as well as factors that may contribute to the spread of radical version of Islam today. According to the author, the factors of radicalization of Muslims in the Adygheya can be divided into two groups - federal and regional. The first concerns the many unresolved methodological issues relating to "New Muslims". As practice shows, the state unequivocal support of the "traditional Muslim clergy" contributes to the isolation of Salafis, limits the possibilities of intraconfessional dialogue. The facts of destruction of mosques, injunction religious books, extra-judicial persecution of Muslims and ban on headscarves (hijabs) in schools in the other regions of the Russian Federation forms the protest discourse. At the regional level a crisis of ethnic ideology Adyghe Khabze, economical crisis and broken social lifts contribute to the radicalization of Muslims. Islamic radicals are very active and professional in social networks, they create the groups whose target audience is youth. The activities of the radical "Internet imams", electronic "religious authorities" are typical for Adygheya and for the whole North Caucasus outside the native region. Their influence, agitation and propaganda are destructive and will have a negative impact in the future. A new trend is the departure of the Adyghe Muslims in ISIL (about 21 people from the beginning of 2015).
\end{abstract}

Key words: Islam, religion, radicalism, salafism, Agygheya Republic, Nothern Caucasus.

УДК 28+323(470.6)

ББК $86.38+66.3(235.7)$

Дата поступления статьи: 28.10.2015

Дата принятия статьи: 11.02.2016

\section{АДЫГЕЯ: ПРОЦЕССЫ РЕИСЛАМИЗАЦИИ И ВЫЗОВЫ ИСЛАМСКОГО РАДИКАЛИЗМА (1990-е - 2015 г.) ${ }^{1}$}

\section{Наима Аминовна Нефляшева}

Кандидат исторических наук, доцент, старший научный сотрудник Центра цивилизационных и региональных исследований, Институт Африки РАН innef@mail.ru ул. Спиридоновка, 30/1, 123001 г. Москва, Российская Федерация

Аннотация. В статье рассматриваются процессы реисламизации в Адыгее в 1990-е гг, их акторы и особенности, а также новые тенденции в 2010-е гг, актуализированные динамикой политического фона, на котором происходило структурирование исламской общины Адыгеи. В статье выделяются факторы, сдерживавшие мусульман республики от радикализма в 1990-2010-е гг., а также факторы, влияющие на распространение радикальных версий ислама в наши дни.

Ключевые слова: ислам, религия, радикализм, салафизм, Адыгея, Северный Кавказ. 
Проблематика изучения (ре)исламизации на современном Северном Кавказе является одной из актуальных не только в силу тех методологических возможностей, которые дает локальный материал для осмысления соотношения общего и особенного в этих сложных процессах, но и потому что существуют и нуждаются в анализе риски распространения радикального ислама в регионы России (и в частности, в иные субъекты ЮФО), казалось бы, имеющие надежную прививку от подобного рода идеологий и движений.

Основой данной работы стали проведенные автором в ходе полевых исследований в 2010-2015 гг. интервью с рядовыми членами уммы Адыгеи, имамами и сотрудниками муфтиата Адыгеи и Краснодарского края, учеными, лидерами национальных организаций, молодежными активистами, а также данные включенных и невключенных наблюдений в мечетях Адыгеи.

Среди северокавказских республик Адыгея занимает особое место, многие процессы, так или иначе связанные с реисламизацией на Северном Кавказе, проявляются здесь в специфической форме и являются отсроченными по времени по сравнению с другими регионами Кавказа. Адыгея интересна тем, что в 1990-е гг. здесь удалось сдержать потенциал радикализации молодежных джамаатов и интегрировать их в Духовное управление мусульман Республики Адыгея и Краснодарского края (далее - ДУМ РА и КК), избежать конфликта между «традиционным» и «новым исламом», переведя его в русло не идеологического противостояния, а теологических бесед и дискуссий, в то время как на восточном Кавказе ситуация складывалась по другому сценарию, а в соседней Кабардино-Балкарии в конечном итоге привела к трансформации одной из мирных общин верующих в боеспособный джамаат и вооруженному выступлению в Нальчике 13 октября 2005 года.

Адыгея - республика и субъект Российской Федерации. По данным на 1 января 2014 г. население Адыгеи составляло 446406 тыс. человек. Согласно Всероссийской переписи населения 2010 г. 61,53 \% населения Адыгеи - русские, 24,33 \% - адыгейцы (западные адыги (черкесы)), 3,54 \% - армя- не, 1,33 \% - украинцы, греки, татары, белорусы, немцы.

Ислам у западных адыгов суннитского толка. Исламские институты отличаются в Адыгее рядом особенностей. Прежде всего, ислам стал распространяться здесь относительно поздно по сравнению с восточным Кавказом - в XIV-XVIII веках.

Ключевым фактором являлось влияние на ислам мощной этнической традиции, выполнявшей основную функцию тотального регулятора всех общественных отношений - Адыгэ Хабзэ. Ислам усваивался по тем матрицам, которые уже были наработаны системой Хабзе, и адыгами воспринято было только то, что не вступало с ней в противоречие. Длительное время и христианская проповедь, и идеи коранического монотеизма не могли поколебать традиционный адыгский миропорядок, основанный на идеях личной свободы, индивидуализме, сословной иерархии и традициях социального одобрения, почти равного по силе одобрению Божественному [5, с. 197].

События Кавказской войны и активизация борьбы адыгов против российского проникновения на Кавказ способствовали ускорению принятия ислама западными черкесами и сделали его идеологической основой консолидации адыгских субэтнических групп. Однако не приходится и говорить о глубоком проникновении исламской догматики в сознание адыгов. В обрядовой сфере, за исключением похоронного ритуала, преобладали языческо-христианские традиции [12, с. 37].

Наканунереволюционных событий 1917 г. продолжался процесс освоения ислама адыгской этнокультурной традицией, исламские институты у адыгов были рыхлыми и неоформленными структурами.

Вторая особенность выражается в том, что у западных адыгов уже в конце 1920-х гг. полностью были утрачены собственные, пусть и недостаточно развитые, исламские институты - шариатское судопроизводство, мусульманские школы, мечети как культурно-просветительские и идеологические центры, традиции совершения хаджа. К концу 1920-х гг. все обязанности имамов (эфенди), кроме культовых, были перераспределены между государственными структурами. До 1929 г. мечети в Адыгее работали. По данным официальной 
статистики, в 1924 г. в 45 аулах действовало 26 мечетей [1, 109-109 об.].

Процессы реисламизации в Адыгее, начавшиеся в 1990-е гг., определялись наличием длительного исторического разрыва с исламской духовной традицией. В республике не было ни одной мечети: ни действующей, ни исторически сохранившейся. Процессы реисламизации выразились в создании самостоятельного муфтиата (ДУМ РА и КК) в 1991 г. и районных мусульманских организаций, строительстве мечетей, возобновлении хаджа, распространении исламской литературы, появлении первых переводов Корана на адыгейский язык; тогда же первые студенты из Адыгеи (это были единицы) поехали учиться в университеты Сирии и ОАЭ на шариатские факультеты.

По данным на декабрь 2015 г. в Духовное управление мусульман Республики Адыгея и Краснодарского края входят 12 районных религиозных организаций мусульман, а также 3 городские организации (Майкопа, Краснодара и Адыгейска). В собственности религиозных обществ мусульман Адыгеи и Краснодарского края находится 47 мечетей в Республике Адыгея, в Краснодарском крае - 5 мечетей и 3 молельные комнаты (в Краснодаре, Новороссийске и Белореченске). Главная мечеть республики - Соборная мечеть г. Майкопа. Муфтием республики Адыгея в ноябре 2012 г. избран Аскарбий Карданов.

Отличительной чертой процессов реисламизации в Адыгее в 1990-е гг. являлось активное участие в них черкесов-репатриантов (потомков мухаджиров, депортированных в Османскую империю в ходе и после Кавказской войны): они были первыми муфтиями, преподавали ислам, арабский язык, учили Корану, были имамами во многих мечетях Адыгеи, в том числе и в Соборной мечети г. Майкопа [11, с. 39-41].

Адыги-репатрианты, ставшие имамами в мечетях в начале 1990-х гг., по существу формировали новый исламский дискурс на Северо-Западном Кавказе. Заметная культурная дистанция между репатриантами и российскими адыгами, сложившаяся в течение более чем 140 лет проживания в различных политических и культурных контекстах, проявлялась в 1990-е гг. и в уровне, и в характере усвоения учения Мухаммада. Явный разрыв в уровне образования существовал между имамами-репатриантами и местными служителями исламского культа. Для первых был характерен высокий уровень мусульманского образования, знание арабского и свободное чтение Корана, возможность апеллировать в случае спорных вопросов к фетвам и мнению известных мусульманских ученых древности и современности. Возможности вторых были более скромными и ограничивались знанием основных молитв и обрядовой практики поминально-погребального цикла, сложившегося в Адыгее.

В настоящее время все имамы РА, в том числе и репатриировавшиеся служители исламского культа, имеют гражданство РФ. В Соборной мечети Майкопа, в мечетях Адыгейска и поселка Яблоновский ведут службу российские черкесы, получившие образование за границей и составившие достойную конкуренцию своим предшественникам 1990-х годов.

На основании проведенных автором исследований, прежде всего включенного наблюдения и интервью с имамами аульных мечетей, представляется возможным говорить, что посещаемость мечетей в различных районах Адыгеи неравномерна. Наибольшая религиозная активность наблюдается в городах Майкопе и Адыгейске и крупных населенных пунктах или аулах, расположенных возле Краснодара, в пос. Яблоновском, Энеме и аулах Тлюстенхабле и Новая Адыгея. По оценкам самих имамов, на пятничной хутбе в Соборной мечети бывает до 500 мусульман. Своеобразным центром мусульманской активности стала мечеть пос. Яблоновский, сюда в пятницу приходят примерно $300-$ 400 человек. По праздничным дням в КурбанБайрам и Ураза-Байрам верующие вынуждены молиться в два захода, так как помещение не в состоянии вместить всех молящихся. Такой большой поток прихожан обеспечивается не за счет местного населения, а за счет мусульман, приезжающих на молитву из Краснодара. Во время пятничных хутб Яблоновская мечеть наполняется в основном представителями нечеркесской национальности, адыги в процентном отношении прихожан составляют лишь $10 \%$. 
В краевом центре мечети нет, поэтому мусульмане молятся в ближайшем к Краснодару Тахтамукайском районе. Руководство ДУМ РА и КК с 2008 г. неоднократно обращалось к прежнему губернатору Краснодарского края А.Н. Ткачеву по вопросу о необходимости строительства мечети и организации мусульманского кладбища в Краснодаре и Сочи. К концу 2015 г. тема строительства мечети в краевом центре была заморожена, хотя в предолимпийский период было сделано немало заявлений со стороны краевых властей о постройке мечети в Краснодаре.

Гораздо меньше исламизированы Шовгеновский и Кошехабльский районы, где нет образованных имамов и традиции Хабзэ преобладают над исламом. Здесь практически нет молодых людей, заинтересованных в изучении ислама. Даже в пятницу в аулах Пшичо, Пшизов, Хатажукай, Блечепсин, Ходзь в мечети не проводится проповедь. В мечети Панахеса собирается около 20-25 человек. Практически пустуют мечети в ауле Нешукай Теучежского района [8]. В середине 2010-х гг. в некоторых аулах появились немногочисленные группы молодых людей (называемых в народной традиции «бородачи»), придерживающиеся салафизма. В мечетях они молятся отдельно, на похоронах агитируют против захоронения по традиционному адыгскому обряду, допускают посещения похорон мужчинами без головного убора, призывают не раздавать вещи покойного, не жарить поминальные лепешки в течение года по четвергам, не устраивать поминки на 7-й и 40-й день, не раздавать соболезнующим после похорон пакеты с едой. Средний возраст мусульман в таких группах 20-25 лет. Чтобы избежать раскола мусульманского сообщества и «вражды между жителями», в Шовгеновске, например, по разрешению муфтия такая группа мусульман молится отдельно в одной из мечетей, со своим имамом ${ }^{2}$.

Все мечети Адыгеи построены в постсоветский период, Соборная мечеть Майкопа возведена на средства шейха княжества РассЭль-Хайм, ОАЭ, некоторые мечети в аулах при активном участии репатриантов и местных бизнесменов. В настоящее время усиливается роль Соборной мечети Майкопа как центра активизации и коммуникации мусульман. Че- рез институт мечети происходит и активизация родственных контактов - родственники видят друг друга на намазе гораздо чаще, чем в обычной жизни. Между мусульманами мечети действует смс-оповещение. Примерно раз в три дня рассылаются сообщения с просьбами о помощи в связи с переездом, объявления о продаже машины, о продаже халяльного мяса, поздравления с рождением детей, извещение о похоронах и т. д.

В отличие от регионов Восточного Кавказа, где де-факто существует шариатское судопроизводство, особенно при разборе дел, связанных с примирением кровников, дел брачного, семейно-имущественного и наследственного характера, ДУМ РА и КК не поддерживает идею возрождения шариатских судов, о чем было заявлено в официальной резолюции съезда мусульман 20 сентября 1997 года. ${ }^{3}$

С 1995 г. мусульмане Адыгеи и Краснодарского края возобновили паломничествохадж. В течение 2003-2015 гг. наибольшее количество паломников (151 человек) приходится на 2012 г., когда все путевки были оплачены Главой Чечни Рамзаном Кадыровым из Фонда Ахмата Хаджи Кадырова, наименьшее число (3 и 20 человек) отмечено соответственно в 2005 и 2015 годах.

Со второй половины 2000-х гг. заметное участие в делах уммы Адыгеи принимает Глава Чечни Р. Кадыров: Фонд Ахмата Хаджи Кадырова регулярно присылает продукты к праздникам Ураза-Байрам и Курбан-Байрам, выделяет бесплатные путевки для совершения паломничества (хаджа), заявляет о готовности финансировать постройку второй мечети и медресе в Майкопе [2; 10; 19]. В 2014 г. мусульмане Адыгеи в последний раз имели возможность получить бесплатные путевки для совершения хаджа из Фонда Ахмата Кадырова, от финансовой поддержки в строительстве новой мечети и медресе в Майкопе ДУМ РА и КК воздержалось.

В 1990-е гг. ДУМ РА и КК большую часть своей деятельности посвящало решению обрядовых вопросов - упорядочению заключения накяха (брачного договора), регламентации похоронной обрядности (отмене сооружения железных оградок вокруг могил и прекращению огораживания больших участков земли для будущих семейных захоронений, отме- 
не пышных сорокадневных поминок). Зачастую шумное и навязчивое пропагандистское обеспечение этих, безусловно, важных инициатив ДУМ значительно превосходило их актуальность для ситуации конца 1990-х годов.

В современном исламском дискурсе Адыгеи, гораздо более сложном по сравнению с периодом 1990-х гг., тема обрядовой регламентации и конструирования новой обрядности также занимает особое место. Некоторыми имамами Адыгеи было негативно воспринято возрождение традиционного весеннего черкесского Нового года, инициированное в 2009 г. властями и интеллигенцией республики. На пятничных проповедях в некоторых мечетях говорилось о недопустимости участия мусульманина в праздновании, так как Новый год «является языческим обрядом и не имеет никакого отношения к Исламу, вследствие чего участие в нем является «харамом», то есть запретным для мусульман» [3]. Имам пос. Яблоновский Анзор Дзеукожев публично заявлял, что «попытки навязать адыгам обычай справлять языческий праздник являются оскорблением их предков - мусульман, отказавшихся от язычества, чьей кровью обагрена вся адыгская земля и которые покинули свою родину ради сохранения верности Слову Аллаха».

Неоднозначную реакцию у представителей ДУМ РА и КК вызвало возведение Монумента Памяти и Единения, установленного в 2014 г. в Майкопе к 150-летнему юбилею окончания Кавказской войны рядом с Соборной мечетью. На этапе публичного обсуждения памятника с его автором, скульптором и художником А. Берсировым, руководство ДУМ РА и КК несколько раз высказывалось против размещения символов черкесского языческого пантеона на этом обелиске на том основании, что памятник находится рядом с мечетью, символизирующей торжество монотеизма.

В целом начиная с 1990-х гг. мусульмане Адыгеи избежали внутриконфессионального конфликта, как правило, ведущего к дальнейшей радикализации молодежи, появления подпольных молодежных джамаатов, автономных от ДУМ РА и КК, и оттока мусульман в те республики Северного Кавказа, где вооруженное экстремистское подполье было наиболее активным.
Однако в течение 2000-х гг. зафиксированы отдельные случаи, имевшие достаточный потенциал, чтобы спровоцировать внутриконфессиональное напряжение. Прежде всего это дела Р. Цея ${ }^{4}$ и имама Н. Абази ${ }^{5}$. Оба репатрианты из Косово.

Адыги-репатрианты из югославского Косово в 1990-е гг. были специфической группой, серьезно влияющей на умонастроения молодых мусульман в Адыгее. Напомню, что в августе 1998 г. на основании Постановления Правительства РФ № 690 «О неотложных мерах государственной поддержки переселения адыгов (черкесов) из Автономного края Косово (Союзная Республика Югославия) в Республику Адыгея» при поддержке Международной Черкесской Ассоциации (МЧА) 200 человек (21 семья), потомков мухаджиров из Косово, вернулись в Адыгею. Вскоре на окраине Майкопа для косовских черкесов был построен аул Мафэхабль со своей мечетью. Юридические, экономические и психологические сложности процесса репатриации наложились на определенную ментальную дистанцию между косовскими и российскими адыгами-мусульманами, определяемую различными политическими и этнокультурными контекстами, в которых развивались адыги РФ и диаспоры. Сложившиеся напряженные взаимоотношения между Р. Цеем и руководством ДУМ РА и КК как нельзя лучше отражают эту реальность.

Беглые упоминания о конфликте в местной прессе не дают представления о сущности расхождений между ДУМ и Р. Цеем. По словам бывшего муфтия Адыгеи и Краснодарского края Н. Емижа, «он сталкивал молодежь с взрослым населением, с Духовным управлением, с Советом Духовного управления» [7]. В ходе проведенных интервью стало известно, что Р. Цей упрекал муфтия за незнание, по его мнению, нюансов отправления культа, не раз публично заявлял о своей оппозиции руководству ДУМ РА и КК, а также о своих претензиях на пост муфтия, обвинял местных имамов в низком образовательном уровне и незнании арабского языка. К весне 2004 г. противостояние достигло своей критической точки, и Р. Цей был депортирован в Турцию. Официальной причиной депортации стало нарушение паспортно-визового режима, 
а именно непродленный вид на жительство. Р. Цей подавал апелляции (в суды городского и республиканского уровня и в Верховный суд России) на решение паспортно-визовой службы республики, но они были отклонены. Сегодня Р. Цей проживает в Турции. Публичную протестную реакцию со стороны молодых мусульман, посещавших уроки Р. Цея, на его депортацию удалось погасить путем длительных переговоров с мусульманами представителей власти Адыгеи.

С 2005 г., после вооруженного мятежа в Нальчике, мусульмане Адыгеи впервые попадают в зону внимания МВД, однако следует отметить, что за редкими исключениями силовики в Адыгее не вышли за рамки правового поля, как это было в тот же хронологический период в КБР, Дагестане, КЧР.

Имам Адыгейска Абази Наджмудин был задержан в апреле 2006 г. на фоне волны профилактических мероприятий и задержаний, проведенных по следам событий в Нальчике в 2005 г. - первой половине 2006 года. Этому предшествовало резонансное задержание сотрудниками МВД Адыгеи в октябре 2005 г. после ночного намаза шести прихожан Соборной мечети г. Майкопа. Их продержали всю ночь в здании Управления, добиваясь под пытками признания в причастности к ваххабизму. Пострадавшие подали заявление в прокуратуру Адыгеи, было возбуждено уголовное дело. В МВД Адыгеи прошла пресс-конференция, на которой министр внутренних дел Адыгеи В. Смирнов публично извинился за действия сотрудников милиции в Соборной мечети и обещал наказать виновных. Вскоре, примерно через две недели, сотрудником МВД Адыгеи был избит в подъезде своего дома имам Соборной мечети Руслан Хакиров, покинувший Адыгею и ныне работающий имамом в мечети аула Хабез КЧР. В апреле 2006 г. в одном из крупных аулов, Новая Адыгея, милиция с собаками обыскивала машины с мусульманами, направляющимися на традиционное пятничное моление.

Абази были предъявлены обвинения в организации экстремистского сообщества, разжигании религиозной нетерпимости, хранении литературы экстремистского толка. Абази был осужден Теучежским районным судом по ст. 238 ч. 1 УК РФ за «хранение в мечети в целях сбы- та, а также сбыт товаров и продукции, не отвечающей требованиям безопасности жизни и здоровью потребителей». Наказание в виде штрафа составило 10000 рублей [14]. Республиканский суд Адыгеи, куда обратился истец, удовлетворил кассационную жалобу Абази о незаконном привлечении его к уголовной ответственности. Теучежская районная прокуратура закрыла уголовное дело, переквалифицировав в административное правонарушение. При этом была снижена и сумма штрафа с 10000 рублей до 1 500-3 000 рублей.

Эти события: и депортация Р. Цея, и задержание, а затем суд над Н. Абази, и обыски мусульман - стали для Адыгеи резонансными. Ничего подобного ранее в республике не случалось. В умме начали формироваться протестные настроения и дискурс ущемления прав мусульман. Только благодаря подвижкам в деятельности муфтиата, о которых я скажу ниже, пересмотру дела Н. Абази, длительным переговорам с мусульманами со стороны местной власти удалось удержать формирующийся протест в правовом поле и сдержать активистов от публичных митингов и пикетов.

Из самых заметных событий 2005 г., важных в контексте нашей статьи, отметим реакцию мусульман, входящих в руководство АРОД «Черкесский конгресс», на инициативу Общероссийского благотворительного фонда Николая Чудотворца. Фонд планировал строительство памятника этому православному святому в столице Адыгеи Майкопе. Строительство памятника Николаю Чудотворцу на территории одного из главных парков города вылилось в протесты адыгских национальных движений. В начале июля в течение недели 20 человек, представителей «Черкесского конгресса», пикетировали и фактически остановили стройку. Администрацией Майкопа был проведен круглый стол с участием инициаторов пикета, а также лидеров религиозных конфессий, на котором было решено приостановить строительство. Памятник вскоре был установлен на территории воинской части, чья земля находится в федеральной собственности. Пожалуй, это первое в новейшее время проявление публичной политической активности мусульман Адыгеи.

С 2005 г. в Адыгее меняется политический фон, на котором происходит дальнейшее 
структурирование уммы республики, о чем следует сказать особо, поскольку появились риски слияния национального и религиозного активизмов. Кремль начинает проект укрупнения регионов. Высказывания представителей краснодарской краевой и кремлевской администрации давали повод предполагать, что вскоре Адыгея, вовлеченная в этот масштабный проект, потеряет свой республиканский статус. Мусульмане не выступали как самостоятельные акторы развернувшихся событий, но были интегрированы в адыгские общественные организации, активно действовавшие на политическом поле в 2004-2006 годах.

Проект укрупнения повлек за собой активизацию общественно-политических национальных движений, как славянских, так и черкесских - «Союза славян Адыгеи» и «Черкесского конгресса». «Союз славян», наряду с «Адыгэ Хасэ», является политическим старожилом Адыгеи, а «Черкесский конгресс» был создан в 2004 г. в немалой степени под влиянием растущей активности первой. Если для «Союза славян» программным пунктом была идея возвращения Адыгеи в Краснодарский край ${ }^{6}$, то в дискурсе «Черкесского конгресса» существование республики и государственность Адыгеи концептуализировались как гарантии сохранения адыгской идентичности. «Черкесский конгресс» предложил альтернативный вариант укрупнения регионов объединение в составе России Адыгеи, Кабарды, Черкесии и Шапсугии в Адыгскую (Черкесскую) республику в рамках исторических границ. Одновременно «Черкесский конгресс» обратился в Государственную Думу РФ и в Европарламент с предложением признать Россией факт геноцида адыгов в период Кавказской войны. Государственная Дума РФ затягивала с ответом «Черкесскому конгрессу», он был получен только в январе 2006 г. и заключался в следующем: «По данным Института российской истории $\mathrm{PAH,} \mathrm{репресси-}$ ям по национальному признаку в советский период подверглись 16 этносов, еще 45 этносов были затронуты репрессиями частично. Адыгейцы (черкесы) в этом списке не фигурируют», - говорилось в письме из ГД РФ [9].

Подобный ответ ускорил процессы активизации черкесского национализма, и 21 мая 2006 г. был созван чрезвычайный съезд ады- гов. Единственный вопрос повестки этого съезда - вопрос сохранения статуса Адыгеи. Съезд принял резолюцию, по резкости формулировок не сравнимую ни с каким-либо документом адыгских национальных движений 1990-2000-х гг.: «В случае принятия на уровне власти решения о проведении всенародного (с участием всего населения) референдума по статусу республики адыгский народ не участвует в референдуме» [13].

На съезде Мурат Берзегов, руководитель АРОД «Черкесский конгресс», впервые публично высказал опасения по поводу возможности радикализации мусульманской молодежи республики: «Часть мусульманской адыгейской молодежи, не имеющая возможности для социального продвижения в современном коррумпированном российском обществе, вынуждена замыкаться в независимые от Духовных управлений мусульман локальные религиозные группы, возможность перерождения которых в радикальные структуры, вопреки традиционным для адыгов-черкесов миролюбию и гибкости, возрастает при складывающихся условиях» 7 .

Однако ожидаемой радикализации джамаата Адыгеи не произошло. В условиях риска слияния национального и религиозного протеста тема укрупнения Краснодарского края за счет Адыгеи была снята Москвой. Муфтий РА и КК Н. Емиж начал активно работать над интеграцией мусульманской молодежи в ДУМ РА и КК. При его поддержке при ДУМ был создан Молодежный Совет, им был взят последовательный курс на удержание молодежи, в том числе и тех мусульман, кто закончил вузы за границей, в рамках муфтиата и на нейтрализацию тех площадок, где могли сформироваться экстремистские идеи и структурироваться радикальные молодежные джамааты.

Единственными проявлениями радикализма можно считать «дело Аскера Сетова» ${ }^{8}$, спровоцировавшее задержания и аресты мусульман, и «дело Закира Артеева» 2011 года. ${ }^{9}$ Резонансные единичные обыски в домах мусульман проводились в 2009-2010 годах.

Хотя в Адыгее не дошло до массового задержания людей по признаку наличия бороды и коротких штанов, как это имело место в КБР и Чечне и было типично для КЧР в 2011- 
2012 гг., фиксируются единичные случаи, когда наличие бороды оказывалось достаточным для повышенного внимания силовиков, для оперативных действий, увольнения с работы и проявления подозрительности людей.

Таким образом, Адыгея остается едва ли не единственной республикой Северного Кавказа, где не произошло радикализации мусульман, а именно: не появилось радикальных джамаатов, не входящих в ДУМ РА и КК, не фиксировалось участие мусульман Адыгеи в вооруженном экстремистском подполье в других республиках Северного Кавказа. Протестные настроения, если и имели место в 2004-2006 гг., были связаны с возможной потерей Адыгеей статуса республики и не сформировались в оформленный протест, реализуемый вне правового поля РФ. Случаи Сетова и Артеева, пожалуй, являются единственными явными проявлениями исламского радикализма в Адыгее. Вопрос о том, почему же в Адыгее не произошло радикализации мусульман, имеет принципиальное значение. Как имеет значение и то, насколько стабильна и долгосрочна такая ситуация.

1. Одним из важных является географический фактор, а именно анклавное положение Адыгеи в Краснодарском крае. Сказывается также относительная удаленность Адыгеи от региональных транспортных узлов коммуникаций. Адыгея, таким образом, является субъектом РФ, территориально и административно удаленным от кавказских республик, где мусульманское население является преобладающим, а следование нормам ислама - определяющим при социализации личности.

2. Степень распространения ислама в Адыгее невысока. На фоне общего количества населения города Майкопа и республики практикующих мусульман в республике мало. Большая часть населения ограничивается празднованием Ураза-Байрама и Курбан-Байрама. В месяц Рамадан соблюдение поста для большинства населения ограничивается только запретом на употребление пищи в светлое время суток, без совершения предписанных в исламе ритуальных практик.

3. Мусульмане Адыгеи слабо структурированы и политически неактивны. Политическая активность мусульман в Адыгее не проявляется в рамках самостоятельных структур - общественных организаций, тем более, политических движений. «Черкесский конгресс», основанный в 2004 г. и к 2014 г. прекративший свое существование, был единственной черкесской общественной организацией (движением), в руководстве которой были практикующие мусульмане. В Адыгее нет и большого притока мусульман, получивших образование за границей, способных привнести несвойственные для региона идеи и обрядовые практики. По данным 2014 г., в ближневосточных вузах учится всего 12 человек. Известны случаи, когда мусульмане, получившие шариатское образование за границей, предпочитают не возвращаться на родину, считая пребывание в мусульманской стране безопасным для будущего детей и для сохранения и укрепления веры.

4. О слабом значении ислама в жизни Адыгеи свидетельствует и то, что исламская риторика не используется в «дискурсе власти» как инструмент ее легитимизации. Глава республики А. Тхакушинов, как и прежние президенты А. Джаримов и Х. Совмен, ограничивается ритуальными официальными поздравлениями мусульман с двумя главными праздниками мусульманского календаря и посещением в праздничные дни Соборной мечети Майкопа. В отличие от глав республик восточного Кавказа, где исламский дискурс является частью «сценариев власти», ни экс-президент X. Совмен, ни нынешний глава А. Тхакушинов не совершают намаз, не посещают хутбы, не были в хадже, не жертвовали средств на мечети и мусульманскую благотворительность.

5. Светский сегмент и светское образование остаются в Адыгее востребованными. При общем системном кризисе образования АГУ остается активно развивающимся университетом с сохранившимися на некоторых факультетах традициями комплексного образования, дипломы которого конвертируются на региональном рынке. В условиях политического кризиса и политического напряжения на Кавказе АГУ и другой крупный вуз Адыгеи МГТУ скорее выполняют социально-стабилизирующую роль и выступают как инструменты социальной политики, способные завлечь молодых людей в аудитории. 
6. Силовики в Адыгее в 2000-2010-е гг. были не так жестки, как в Дагестане и в Кабардино-Балкарии, и за редким исключением оставались в правовом поле. Они удержались от массовых задержаний людей, внешность которых указывала на следование исламу (борода, короткие штаны, хиджаб с закрытым подбородком), от внесудебных преследований, пыток мусульман, закрытия мечетей, массовых задержаний верующих и изъятия книг из мечетей и домов мусульман. Тем более от насильственного сбривания бород и физического насилия над женщинами в хиджабе. Необоснованные задержания и обыски носили единичный характер.

7. Одна из ключевых причин отсутствия радикального ислама в Адыгее заключается в том, что тема противостояния Адыгэ Хабзэ и ислама как конкурирующих идеологий не получила здесь своего дальнейшего развития, как в КБР, и не вылилась в противостояние сторон. По данным социологического исследования, проведенного в 2010-2011 гг. АРИГИ, ответы, полученные на вопрос о соотношении адыгства и ислама, коррелируют с ответами, полученными на вопрос о соотношении Адыгэ Хабзэ и шариата. Большинство респондентов (56 \%) указало, что для них нормы Адыгэ Хабзэ предпочтительнее [18, c. 136]. Дискурс органичного взаимодействия ислама и Хабзэ занимает особое место в проповедях имамов Адыгеи. Среди мусульман Адыгеи удалось погасить межпоколенческое напряжение, еще 10 лет назад грозившее перерасти во внутриконфессиональный конфликт.

Однако представляется возможным говорить о рисках радикализации мусульман в Адыгее при наличии факторов, в совокупности способных сработать как катализатор. Можно разделить их на факторы внешние, федерального порядка, и на внутренние, связанные со спецификой развития ислама в Адыгее.

1. Основная проблема современной исламской политики РФ заключается в отсутствии новой методологической рамки в отношении «новых мусульман», способов их интеграции в современную политическую жизнь и использовании их как ресурса общественной стабилизации. В официальном политическом дискурсе доминируют методологически неработающие категории «традиционный ис- лам» и «традиционное духовенство». Акции в других регионах России (Дагестане, Чечне, КБР, Поволжье) в виде сноса мечетей, задержаний и пыток мусульман, судебных запретов на мусульманские книги, запретов ношения хиджаба все более выталкивают «новых мусульман» (салафитов) из правового поля и способствуют их радикализации.

2. В связи с экономическим кризисом в Адыгее ожидается сокращение бюджетных поступлений и резкое ухудшение качества жизни, тем более собственное производство в республике практически не развивается. При растущем штате республиканских чиновников среднестатистический житель республики не испытывает чувства защищенности и социальной справедливости. Налицо разрыв между официальными декларируемыми лозунгами и реальной жизнью местных политических элит. Социальное неравенство воспринимается молодыми людьми очень остро, их здоровые амбиции наталкиваются на «задраенные люки» государственных и общественных институтов, в результате увеличивается степень допустимости радикальных настроений и поступков.

В Адыгее остается высоким уровень безработицы. По данным Росстата, уровень безработицы в Адыгее в 2014 г. один из самых высоких в ЮФО и составляет 1,2 \% [16]. Наблюдается отток экономически активного населения из республики в Краснодарский край и другие регионы, который, однако, не может сдерживать социальное напряжение в Адыгее до бесконечности. Так, согласно исследованиям Росстата, в 2007 г. численность экономически активного населения в Адыгее составила 208 тыс. человек, а в 2012 - уже 204 тыс. человек, то есть в течение 5 лет республику покинули 4 тыс. трудоспособных граждан.

3. Усугубляется системный кризис национальной идеологии Адыгэ Хабзэ, что выражается в разрыве преемственности социальных практик, кризисе этнической идентичности, резком снижении ее действенной силы. По мнению авторитетного специалиста Б. Бгажнокова, «в ту нишу сознания (дискурсивного и практического), которую традиционно занимает адыгство, вторгается и постепенно разрастается, оттесняя этику, пустое пространство морального невежества, негативизма, апатии» $[5$, 
c. 86]. Последствия этих процессов справедливо характеризуются ученым как «гуманитарная катастрофа» [5, с. 86-87].

4. Имеет значение и включенность Адыгеи в общекавказский контекст, а именно невозможность анализировать динамику уммы Адыгеи вне процессов, происходящих в соседних республиках КБР и КЧР. Информация из КБР о внесудебных преследованиях и пытках мусульман значит для местной уммы не меньше, а часто и больше, чем общероссийская и мировая мусульманская повестка. Решение суда по делу о нападении боевиков на Нальчик в 2005 г., как и следствие, проходившее с нарушениями законодательства, устрашающие условия содержания подследственных в СИЗО г. Нальчика, применение пыток к подсудимым, активно обсуждались мусульманами республики ${ }^{10}$.

5. Нельзя сбрасывать со счетов и реакцию российских властей на обращения черкесской диаспоры в Сирии (в Сирии 120 тыс. черкесов) с просьбой об эвакуации на историческую родину в связи с гражданской войной. Несмотря на многочисленные обращения в Кремль в течение 2011-2012 гг. региональных черкесских общественных организаций, съезд адыгов в 2012 г. в Майкопе, поддержавший репатриацию, позитивные прогнозы делегации Совета Федерации, работавшей в Дамаске в 2012 г., просьба осталась без официального ответа. Справедливости ради надо сказать, что все сирийские черкесы (по данным на январь 2016 г. в Адыгее, КБР и КЧР проживает около 2 тыс. человек), просившие визы для въезда в Россию в 2011-2014 гг., при всех трудностях их получили, как и позже получили легальный правовой статус - разрешение на временное проживание или вид на жительство. В Адыгее и КБР сирийские черкесы курируются официальными структурами, отвечающими за связи с соотечественниками, имеют право на бесплатную медицинскую помощь и обучение на бюджетной основе в вузах Адыгеи и Кабардино-Балкарии [6]. Однако все заботы по их обустройству, обучению русскому языку, поискам работы, жилья, психологической адаптации, обеспечении лекарствами легли на местных граждан и активистов.

В целом в публикациях федеральных СМИ вплоть до осени 2015 г. доминировал негативный дискурс о сирийских черкесах, их возможное возвращение на родину оценивалось как риск распространения «арабской весны», а сами сирийские черкесы - как носители «чужой» культуры и ментальности. В протестном дискурсе мусульман Адыгеи данная ситуация конструируется как политика двойных стандартов. Особенно на фоне всесторонней помощи государства беженцам из Украины, которых не только принимают и обустраивают в РА, КБР и КЧР, но и официально информационно поддерживают процессы их адаптации в новом месте, формируя позитивное общественное мнение.

6 . Актуализируется фактор экспансии идеологии ИГ/ИГИЛ (организация, запрещенная в России) в Адыгее. Только из одного г. Адыгейска с начала 2015 г. уехал в «Исламское государство» 21 человек, в том числе и семьи с детьми.

По данным директора ФСБ Александра Бортникова, озвученным в феврале 2015 г., на стороне «Исламского государства» воюют около 1700 россиян, причем число граждан России в рядах джихадистов за год практически удвоилось [17]. Сирийский фронт оказался привлекательным для большого количества мусульманской молодежи Северного Кавказа. По данным российских официальных лиц, общая численность джихадистов российского происхождения могла составлять не менее 800 (в целом) в 2014 г, а в начале 2015 г. только в одном Ираке доходить до 1700 человек [15]. В основном это представители Дагестана, Ингушетии, Чечни, Кабардино-Балкарии. Есть кавказцы, приехавшие на сирийский фронт из Европы, где они оказались в качестве беженцев еще во время чеченских войн 1990-е гг. или будучи студентами. В социальных сетях набирают обороты дискуссии, в которых обсуждается маргинализация и крах проекта Имарата Кавказа и стремительное выражение лояльности к ИГ всех ключевых амиров Имарата Кавказа в течение первого полугодия 2015 года.

Исламскими радикалами ведется активная профессиональная работа в социальных сетях, создаются группы, целевой аудиторией которых является молодежь. В социальных сетях создано немало групп с патриотическим названием, отсылающим к адыгскому 
дискурсу - в названии присутствуют слова «адыги» или «Черкесия». Как правило, проблематика этих групп формируется по одной схеме - казалось бы, невинное обсуждение традиционных черкесских обычаев и обрядов плавно сводится к теме несоответствия черкесской традиционной культуры исламским ценностям, а затем заканчивается транснациональной джихадистской пропагандой. Типичным для Адыгеи, как и для всего Северного Кавказа, стало появление интернетимамов, электронных «религиозных авторитетов», находящихся за пределами родной республики. Их влияние вполне может пересилить авторитет местного ДУМ РА и КК, и возможная радикализация мусульман в Адыгее будет связана в том числе с их агитацией и пропагандой.

\section{ПРИМЕЧАНИЯ}

1 Исследование выполнено при финансовой поддержке РГНФ, проект № 14-03-00511 «Современные исламские политические концепции в России: идеология и практика».

2 Личный архив автора. Полевые материалы. Тетрадь 2. Л. 22. Июнь 2014 года.

3 Личный архив автора. Полевые материалы. Тетрадь 2. Л. 18. Май 2014 года.

${ }^{4}$ Рамазан Цей - выпускник теологического факультета Амманского университета Иордании, после репатриации на родину стал преподавать в Соборной мечети Майкопа арабский язык и основы ислама, а также в течение двух лет издавал газету «Читай», учредителем которой выступала мусульманская община аула Тахтамукай.

5 Абази Наджмудин - репатриант из Югославии, проживает Адыгее с 1996 года. В настоящее время Главный имам Адыгеи и заместитель муфтия, имам мечети г. Адыгейска.

6 «Союз славян Адыгеи» настаивал в начале 2000-х гг. на принятии «Закона о региональном референдуме о статусе Республики Адыгея». Очевидно, что в случае проведения референдума при $22 \%$ адыгов в республике в то время его результаты были бы предсказуемы и Адыгея бы вошла в Краснодарский край.

7 Личный архив автора. Полевые материалы. Тетрадь 2. Л. 10. Январь 2012 года.

${ }^{8}$ Обстоятельства расстрела КПП таковы. Милиционеры на посту КПП на въезде в Краснодар остановили такси, в котором пассажир заметно нервничал. В ответ на просьбу выйти из машины он выхватил из-за поясного ремня пистолет систе- мы «Стечкин», выстрелил в начальника смены и, ранив его, бросился бежать. В преследовавших его милиционеров Сетов расстрелял 20 патронов. Погиб один и ранены трое милиционеров. Сетов был обвинен и осужден по статье 317 УК РФ (посягательство на жизнь сотрудника правоохранительных органов). По данным правоохранительных органов, Сетов имел отношение к экстремистскому подполью на территории Северного Кавказа.

9 Александр (Закир) Артеев, работавший в редакции газеты ДУМ РА и КК «Свет», в 2009-2010 гг. под псевдонимом «Абу-т-Танвир Кавказский», а также от лица виртуального «Джамаата аль-Гариб» подготовил несколько статей и направил их для размещения на сайте организации «Имарата Кавказ», признанной террористической решением ВС РФ. Артеев призывал адыгов бороться с «оккупационной» федеральной властью и включить адыгские территории в состав «Имарата Кавказ». В 2011 г. Майкопский городской суд приговорил А. Артеева по ч. 1 ст. 280 УК РФ (публичные призывы к осуществлению экстремистской деятельности) и по ч. 1 ст. 205.2 УК РФ (публичные призывы к осуществлению террористической деятельности или публичное оправдание терроризма) к 3 годам и 6 месяцам лишения свободы с отбыванием срока в колониипоселении.

1013 октября 2005 г. произошло вооруженное нападение на столицу Кабардино-Балкарии город Нальчик. Численность боевиков, напавших на город, составляла не менее 250 человек. В результате нападения погибли 35 сотрудников силовых структур и 15 гражданских лиц, 129 силовиков и 66 гражданских лиц были ранены. В результате боев в городе были убиты 95 боевиков. По состоянию на 2009 г. по делу о нападении на Нальчик проходило 58 человек, 56 из которых находились под стражей. Большинство подсудимых находились в заключении без приговора более девяти лет. Приговор по делу о нападении на Нальчик был оглашен 23 декабря 2014 г. в Верховном суде Кабардино-Балкарии. Пятеро обвиняемых были приговорены к пожизненному лишению свободы, трое освобождены с учетом отбытого срока. Остальные приговорены к различным срокам от 9 до 23 лет лишения свободы. Суд также постановил взыскать с каждого из подсудимых по 150-300 тыс. рублей судебных издержек.

\section{СПИСОК ЛИТЕРАТУРЫ}

1. Адыгейский областной административный отдел // Национальный архив Республики Адыгея. Ф. Р-8. - Оп. 1. - Д. 158.

2. Актуальные встречи // Свет. Газета Централизованной религиозной организации Духовно- 
го управления мусульман Республики Адыгея и Краснодарского края. - Майкоп : Качество, 2012. № 1 (59). - С. 1 .

3. Анзор Дзеукожев про так называемый «адыгский» Новый год» // ВКонтакте. Группа «Духовная Черкесия». - Электрон. текстовые дан. Режим доступа: http://vk.com.1.gsr.anonimizing.com/ duhcherk?null. - Загл. с экрана.

4. Бгажноков, Б. Х. Адыгская этика / Б. Х. Бгажноков. - Нальчик : Эль-фа, 1999. - 96 с.

5. Бгажноков, Б. Х. Черкесы (Адыги) / Б. Х. Бгажноков. - Тбилиси : [б. и.], 2010. -411 с.

6. Более 100 студентов-репатриантов из Сирии бесплатно пройдут обучение в вузе КБР // РИА НОВОСТИ, 25 сентября 2013. - Электрон. текстовые дан. - Режим доступа: http://ria.ru/arab_riot/ 20130925/965808776.html. -Загл. с экрана.

7. В Адыгее набирает обороты скандал о депортации репатрианта из Косово // ИA REGNUM, 6 июня 2004. - Электрон. текстовые дан. - Режим доступа: http://www.regnum.ru/news/polit/273225. html. - Загл. с экрана.

8. В ауле Нешукай Теучежского района Адыгеи не совершает молитвы ни один аульчанин. Электрон. текстовые дан. - Режим доступа: http:// www.adigeyaislam.com/ru/files/index.php?newsID= 144\&page=newsdetail. - Загл. с экрана.

9. Госдума РФ не признала факта геноцида адыгского народа. - Электрон. текстовые дан. - Режим доступа: http://rodadygekhase.blogspot.ru/ 2014/06/blog-post_17.html. - Загл. с экрана.

10. Дорогой подарок для мусульман // Свет. Газета Централизованной религиозной организации Духовного управления мусульман Республики Адыгея и Краснодарского края. - Майкоп : Качество, 2007. - № 9 (23). - С. 3.

11. Неугасимый свет ислама. Возрождение Ислама в Республике Адыгея и Краснодарском крае / ЦРО Духовное управление мусульман РА и КК ; отв. Н. М. Емиж. - Майкоп: Качество, 2011. $124 \mathrm{c}$.

12. Нефляшева, Н. А. Эволюции функций и статуса служителей мусульманского культа на Северо-Западном Кавказе (вторая половина XIX - начало ХХ в.) / Н. А. Нефляшева // Вестник МГУ. Сер. 13: Востоковедение. - 2008 . - № 4 . - С. 34-55.

13. Резолюция Чрезвычайного съезда адыгского народа 21 мая 2006 года. - Электрон.текстовые дан. - Режим доступа: http://www.natpressru.info/ index.php?newsid=1735. - Загл. с экрана.

14. Салямова, А. В. Адыгее оправданного имама Н. Абази представили к награде «За духовное единение» / А. Салямова // Кавказский Узел, 6 декабря 2006. - Электрон. текстовые дан. - Режим доступа: http://www.kavkaz-uzel.ru/articles/104901/. Загл. с экрана.
15. Степанова, Е. Спастись и оградиться Россия и «Исламское государство» / Е. Степанова // Российский совет по международным делам. Электрон. текстовые дан. - Режим доступа: http:// russiancouncil.ru/inner/?id_4=6268\#top-content. Загл.с экрана.

16. Федеральная служба государственной статистики. Регионы России. Социально-экономические показатели-2014. - Электрон. текстовые дан. Режим доступа: http://www.gks.ru/bgd/regl/b14_14p/ IssWWW.exe/Stg/d01/03-15.htm. - Загл. с экрана.

17. ФСБ РФ: В рядах боевиков в Ираке воюют почти две тысячи россиян // Российская газета. 2015. - 20 февр. (№ 6607). - С. 7.

18. Ханаху, Р. А. Исламская община в Адыгее: внутренняя динамика и перспективы эволюции (по итогам социологического исследования) / Р. А. Ханаху, О. В. Цветков // Вестник Адыгейского государственного университета. Сер.: Регионоведение: философия, история, социология, юриспруденция, политология, культурология. - 2012. - Вып. 1. C. $132-138$.

19. Чеченская делегация посетила Адыгею // Свет. Газета Централизованной религиозной организации Духовного управления мусульман Республики Адыгея и Краснодарского края. - Майкоп : Качество, 2012. - № 6 (64). - С. 1.

\section{REFERENCES}

1. Adygeyskiy oblastnoy administrativnyy otdel [Adygheya Regional Administrative Department]. Natsionalnyy arkhiv Respubliki Adygeya [National Archive of the Adygheya Republic], F. R-8, Op. 1, D. 158.

2. Aktualnye vstrechi [Urgent Meetings]. Svet. Gazeta Tsentralizovannoy religioznoy organizatsii Dukhovnogo upravleniya musulman Respubliki Adygeya i Krasnodarskogo kraya [Light. Newspaper of Centralized Religious Organization of the Spiritual Administration of Muslims in the Republic of Adygea and the Krasnodar Region]. Maikop, Kachestvo Publ., 2012, no.1 (59), p. 1.

3. Anzor Dzeukozhev pro tak nazyvaemyy “adygskiy" Novyy god [Anzor Dzeukozhev About the So-called "Adyghe" New Year]. VKontakte. Gruppa “Dukhovnaya Cherkesiya”. Available at: http://vk. com.1.gsr.anonimizing.com/duhcherk?null.

4. Bgazhnokov B.Kh. Adygskaya etika [Circassian Ethics]. Nalchik, Elfa Publ., 1999. 96 p.

5. Bgazhnokov B.Kh. Adygi [The Circassians]. Tbilisi, 2010. 411p.

6. Bolee 100 studentov-repatriantov iz Sirii besplatno proydut obuchenie v vuze KBR [More Than 100 Students- Returnees From Syria Will Be Trained at the KBR University for Free]. RIA NOVOSTI, 


\section{РЕГИОНОВЕДЕНИЕ}

September 25, 2013. Available at: http://ria.ru/ arab riot/20130925/965808776.html.

7. V Adygee nabiraet oboroty skandal o deportatsii repatrianta iz Kosovo [Scandal on the Deportation of Immigrant from Kosovo is Gaining in Adygheya]. ИА REGNUM, June 6, 2004. Available at: http://www.regnum.ru/news/polit/273225.html.

8. V aule Neshukay Teuchezhskogo rayona Adygei ne sovershaet molitvy ni odin aulchanin [No One Prays in the Neshukay Aul in the Teuchezhsky Region of Adygheya]. Available at: http:// www.adigeyaislam. com/ru/files/index.php?newsID= 144\&page $=$ newsdetail.

9. Gosduma RF ne priznala fakta genotsida adygskogo naroda [The State Duma of the Russian Federation Did Not Recognize the Fact of Genocide of the Adyghe People]. Available at: http:// rodadygekhase.blogspot.ru/2014/06/blogpost_17.html.

10. Dorogoy podarok dlya musulman [An Expensive Gift for Muslims]. Svet. Gazeta Tsentralizovannoy religioznoy organizatsii Dukhovnogo upravleniya musulman Respubliki Adygeya i Krasnodarskogo kraya [Light. Newspaper of Centralized Religious Organization of the Spiritual Administration of Muslims in the Republic of Adygea and the Krasnodar Region]. Maikop, Kachestvo Publ., 2007, no. 9 (23), p. 3.

11. Emizh N.M., ed. Neugasimyy svet islama. Vozrozhdenie Islama $v$ Respublike Adygeya $i$ Krasnodarskom krae / TsRO Dukhovnoe upravlenie musulman RA $i$ KK [Unquenchable Light of Islam. The Revival of Islam in the Republic of Adygheya and in the Krasnodar Region]. Maikop, Kachestvo Publ., 2011. 124 p.

12. Neflyasheva N.A. Evolyutsii funktsiy i statusa sluzhiteley musulmanskogo kulta na SeveroZapadnom Kavkaze (vtoraya polovina XIX - nachalo $X X$ v.) [Evolution of the Functions and Status of Muslim Clerics in the Northwest Caucasus (the Second Half of the 19th - Beginning of the 20th Century]. Vestnik MGU. Seriya 13: Vostokovedenie, 2008, no. 4, pp. 34-55.

13. Rezolyutsiya Chrezvychaynogo syezda adygskogo naroda 21 maya 2006 goda [Resolution of Emergency Congress of Adyghe People on May 21, 2006]. Available at://www.natpressru.info/ index.php?newsid $=1735$.

14. Salyamova A.V Adygee opravdannogo imama N. Abazi predstavili k nagrade "Za dukhovnoe edinenie" [The Acquitted Imam of Adygheya Was Presented an Award "For Spiritual Unity"]. Kavkazskiy Uzel, 6 dekabrya, 2006. Available at: http:/ /www.kavkaz-uzel.ru/articles/104901.

15. Stepanova E. Spastis i ograditsya - Rossija i "Islamskoe gosudarstvo" [To Escape and to Protect Oneself-Russia and the "Islamic State"]. Rossiyskiy sovet po mezhdunarodnym delam [Russian Council on International Affairs]. Available at: http:// russiancouncil.ru/inner/?id 4=6268\#top-content.

16. Federalnaya sluzhba gosudarstvennoy statistiki. Regiony Rossii. Sotsialno-ekonomicheskie pokazateli-2014 [Federal State Statistics Service. Regions of Russia. Socio-Economic Indicators-2014]. Available at: http://www.gks.ru/bgd/regl/b14_14p/ IssWWW.exe/Stg/d01/03-15.htm/.

17. FSB RF: V ryadakh boevikov v Irake voyuyut pochti dve tysyachi rossiyan [FSS RF: In the Ranks of Militants in Iraq There Are Almost Two Thousand Russians]. Rossiyskaya gazeta, 2015, Feb 20 (no. 6607), p. 7 .

18. Khanakhu R.A., Tsvetkov O.V. Islamskaya obshchina v Adygee: vnutrennyaya dinamika i perspektivy evolyutsii (po itogam sotsiologicheskogo issledovaniya) [The Islamic Community in Adygheya: Internal Dynamics and Perspectives of Evolution (According to the Results of Sociological Research)]. Vestnik Adygeyskogo gosudarstvennogo universiteta. Ser: Regionovedenie: filosofiya, istoriya, sotsiologiya, yurisprudentsiya, politologiya, kulturologiya, 2012, iss. 1, pp. 132-138.

19. Chechenskaya delegatsiya posetila Adygeyu [The Chechen Delegation Visited Adygheya]. Svet. Gazeta Tsentralizovannoy religioznoy organizatsii Dukhovnogo upravleniya musulman Respubliki Adygeya i Krasnodarskogo kraya [Light. Newspaper of Centralized Religious Organization of the Spiritual Administration of Muslims in the Republic of Adygea and the Krasnodar Region]. Maikop, Kachestvo Publ., 2012, no. 6 (64), p. 1. 